${ }^{1}$ Medical Faculty of the University in Pristina with temporary seat in Kosovska Mitrovica, Kosovo, Serbia, Department of pathological physiology. ${ }^{2}$ Medical faculty Foca, University of East Sarajevo, Republic of Srpska, Bosnia and Herzegovina, Department of physiology. ${ }^{3}$ Medical Faculty Foca, University of East Sarajevo, Republic of Srpska, Bosnia and Herzegovina, Department of pathological physiology.

${ }^{4}$ Medical Faculty Foca, University of East Sarajevo, Republic of Srpska, Bosnia and Herzegovina.

Funding: This research received no specific grant from any funding agency in the public, commercial, or not-for-profit sectors.

Recibido el 27 de abril de 2015, aceptado el 27 de enero de

Corresponding author: Mirjana Miric, MD, PhD, University in Pristina with temporary seat in Kosovska Mitrovica, Kosovo, Serbia. Adress: Zoran Glodic (za Bojana Joksimovića), UI Maka Dizdara br. 8, 73300 Foca, Republic of Srpska, Bosnia and Herzegovina. Phone: 0038765373507 joksimovic_bojan@yahoo.com

\section{Reversion of methacholine induced bronchoconstriction with inhaled diazepam in patients with asthma}

\author{
MIRJANA MIRIC ${ }^{1,3}$, SINISA RISTIC ${ }^{2}$, BOJAN N. JOKSIMOVIC ${ }^{3}$, \\ SNEZANA MEDENICA ${ }^{4}$, MAJA RACIC ${ }^{4}$, SLAVICA RISTIC ${ }^{4}$, \\ VEDRANA R. JOKSIMOVIC ${ }^{4}$, MIRJANA SKIPINA ${ }^{4}$
}

\begin{abstract}
Background: Benzodiazepines have a direct bronchodilatory effect. Methacholine is a non-selective muscarinic receptor agonist causing bronchoconstriction. Aim: To examine the effects of inhaled benzodiazepines, modulating bronchoconstriction induced by methacholine in patients with asthma. Patients and Methods: Twelve patients with well controlled asthma were studied. On the first day, after determining the initial values of pulmonary function, a dose response curve was carried out with progressive doses of methacholine. After the last dose, when at least a 20\% drop of the initial forced expiratory volume in the first second $\left(F E V_{1}\right)$ was achieved, vital capacity $(V C)$ and $F E V_{1}$ were measured at 7, 15 and 30 minutes after provocation. On the second day a diazepam aerosol was inhaled by the patients prior to the same protocol with methacholine. Results: In the first day of testing, methacholine inhalation $(6 \mathrm{mg} / \mathrm{mL})$ led to a significant drop in $F E V_{1}$ from 2.98 to $1.69 \mathrm{~L}$. On the second day of study, in the same patients, previous inhalation with diazepam reduced the changes of $F E V_{1}$ after inhalation of methacholine. This parameter decreased from 2.48 to $2.21 \mathrm{~L}$. Conclusions: Inhalation of benzodiazepines reduce bronchoconstriction after a methacholine challenge in patients with asthma.
\end{abstract}

(Rev Med Chile 2016; 144: 434-441)

Key words: Benzodiazepines; Bronchoconstriction; Diazepam; Methacholine Chloride)

\section{Bloqueo de la respuesta bronco constrictora a metacolina con diazepam inhalado en pacientes con asma}

Antecedentes: Las benzodiacepinas tienen un efecto broncodilatador directo. La metacolina es un agonista muscarínico que causa bronco constricción. Objetivo: Evaluar el efecto modulador de la inhalación de diazepam sobre la bronco constricción inducida por metacolina. Pacientes y Métodos: Se estudiaron 12 pacientes con asma bien controlada. En el primer día, se determinó la curva dosis respuesta de parámetros de función pulmonar a una dosis progresiva de metacolina. Después de la última dosis, cuando se consiguió un $20 \%$ de reducción en la capacidad vital forzada en el primer segundo $\left(F E V_{1}\right)$, se midió $F E V_{1}$ y la capacidad vital $(\mathrm{CV})$ a los 7, 15 y 30 min después de la provocación. En el 
segundo día los pacientes se inhalaron con diazepam antes de hacer la prueba con metacolina. Resultados: En el primer día, el FEV 1 bajo de 2,98 a 1,69 l con $6 \mathrm{mg} / \mathrm{ml}$ de metacolina. En el segundo día, la inhalación de diazepam redujo la respuesta a metacolina con una reducción de $\mathrm{FEV}_{1}$ de 2,48 a 2,21 L. Conclusiones: La benzodiacepinas reducen la respuesta de vasoconstricción a metacolina.

\section{A} sthma is a chronic inflammatory disease of the airways characterized by attacks of reversible airflow obstruction that is clinically manifested by dyspnea, wheezing, chest tightness and cough. Asthma is characterized by pathological changes in the airway smooth muscle, which lead to obstruction and bronchial hyperreactivity $^{1,2}$. The opposing actions of the parasympathetic and sympathetic divisions of the autonomic nervous system represent the primary mechanism for regulating airway function. It seems that the bronchial smooth muscle is normally under greater parasympathetic than sympathetic influence ${ }^{3}$. The role of the cholinergic nervous system in the regulation of muscle tone is in reflex bronchoconstriction and increased bronchial gland secretion. Acetylcholine is released from the intrapulmonary endings of vagus nerve branches and directly causes constriction of smooth muscles by stimulation of the muscarinic receptors ${ }^{4}$. Stimulation of the adrenergic sympathetic fibers causes dilation of bronchial and bronchiolar smooth muscle as well as inhibition of glandular secretion. This dilation of the airways smooth muscle is mediated by beta ${ }_{2}$ receptors ${ }^{1-3}$.

Gamma-Aminobutyric acid (GABA), is the mostwidely distributed inhibitory neurotransmitter in the mammalian central nervous system ${ }^{5}$, it binds to postsynaptic receptors, GABAA, GABAB, and GABAC, which are localized in brain and peripheral tissues including the lung ${ }^{6,7}$. GABA receptors modulate cholinergic tone or flow to the airways ${ }^{8}$. Benzodiazepines increase the activity of GABA on the level of the postsynaptic receptors and at the level of all axons in CNS. Benzodiazepines are drugs which are used as muscle relaxants, anticonvulsants and anxiolytics ${ }^{9-13}$. Methacholine acts as a non-selective muscarinic receptor agonist to stimulate the parasympathetic nervous systemand administered in vivo or in vitro mimics the effects of parasympathetic innervation of the musculature of the respiratory tract, thus causing bronchoconstriction $^{14-16 .}$ It is most commonly used for diagnosing bronchial hyperreactivity in asthma patients using the bronchial challenge test. Through this test, the drug causes bronchoconstriction and people with pre-existing airway hyperreactivity, such as asthmatics, will react to lower doses of drug. Methacholine inhalation test also helps in the assesment of disease severity ${ }^{15-17}$. With this research we expect to demonstrate that bronchoconstrictor effects of methacholine in patients with asthma are reduced if the patient has previously inhaled benzodiazepine.

Therefore, the main purpose of our study was to examine the effect of benzodiazepines (diazepam) in modulating bronchoconstriction induced by methacholine, in patients with asthma. For this purpose, we tested: a) spirometric response of variables of lung function in bronchoconstrictor stimulus-methacholine and; b) spirometric response variables on pulmonary function in methacholine after inhalation of diazepam.

\section{Patients and Methods}

Study was carried out in the period JanuaryJuly 2011. The patients were contacted for permission to be included in the study and were asked to give their written informed consent. The clinical trial included 12 patients with well controlled asthma. Clinical evaluations were conducted at the Department of pathological physiology, Faculty of Medicine in Foca, with assistence of department of pneumophtisiology at University Hospital-Foca, Republic of Srpska, Bosnia and Herzegovina. The local Ethics Commitee revised and approved this protocol.

Functional testing of respiratory system consisted of the determination of the vital capacity (VC), forced expiratory volume in first second $\left(\mathrm{FEV}_{1}\right)$, Tiffeneaux index $\left(100 \times \mathrm{FEV}_{1} / \mathrm{VC}\right)$, resistance to air flow in the airways (Rt) and intrathoracic gas volume (ITGV). From obtained values the specific resistance was calculated $(\mathrm{SRt}=\mathrm{Rt} \mathrm{x} \mathrm{ITGV})$. Obtained values for VC and $\mathrm{FEV}_{1}$ were compared with the expected table values of the European 
Commission for Steel and Coal (Jonasset, 1960). Functional assessment of the respiratory system is done with the help of spirometer of the "Jaeger" calibration pump and physical plethysmograph of the "Jaeger" Werzburg. Intrathoracic gas volume and resistance airway was measured by body plethysmography ${ }^{18}$.

In order to detect changes in airflow after inducing methacholine in patients with asthma, the index of bronchial reactivity was calculated. Bronchial reactivity index was defined as the log of the percent decline in $\mathrm{FEV}_{1} / \log$ final histamine dose after adding 10 to eliminate negative values ${ }^{19}$. Bronchial reactivity was tested by using aerosol of methacholine (Acetyl- $\beta$-methylcholine chloride) as inhalation test,manufactured by Sigma - Aldrich Chemie GmbH, Product Number: A2251. Methacholine was used as a solution for inhalation, at room temperature, as recommended elsewhere ${ }^{17}$.

The group of 12 asthmatic patients, which were treated by aerosol of methacholine was investigated in the course of two consecutive days:

First day: After determining the initial values of pulmonary function, dose response curve were made for the following doses of methacholine until a maximum response: $0.2,0.6,2.0,6.0$, and 20.0 $\mathrm{mg} / \mathrm{mL}^{20}$. After the last dose, when at least a $20 \%$ drop of the initial $\mathrm{FEV}_{1}$ value was achieved, we measured $\mathrm{VC}, \mathrm{FEV}_{1}, 7,15$ and 30 minutes after provocation. Patients were in seated position and inhaled methacholine as a nebulization through the mouth. The nose was sealed with cotton wool. Each inhalation lasted two minutes and the device used for inhalation was the "Inhalet" type INHO2 (IEVT). The air flow during inhalation was $5 \mathrm{~L} / \mathrm{min}$ and size of the particles obtained spray, ranged from 0.5 to $5.0 \mathrm{Nm}$. The flow of dispersed liquid was $0,2 \mathrm{ml} / \mathrm{min}$. After each dose of inhaled methacholine, the same parameters of lung function were determined in the patients. The provocative dose (PD), by definition, is the dose that results in the desired response and represents a reflection of the sensitivity of airways. The dose of provocative substance which caused at least a $35 \%$ change in RT and SRt (proposal of the European Society for Clinical Respiratory Physiology-SEPCR) was considered clinically significant ${ }^{21}$.

Second day: The inhalation of aerosol particles, which comprised at least 10 percent by weight of diazepam (Apaurin, Krka) and less than 90 percent by weight of water, was given to the same group of patients. Vials of $10 \mathrm{mg} / 2 \mathrm{~mL}$ were used. The nose was closed with soft plastic clips like clothespins, which pinched the nostrils together. Benzodiazepines containing aerosols were delivered using the inhalation device "Inhalet" type INHO2 (IEVT). The device consisted of three elements: an element for heating a benzodiazepine containing composition to form a vapor; an element allowing the vapor to cool, thereby providing a condensation aerosol; and, an element permitting the patient to inhale the aerosol. The air flow during inhalation was $5 \mathrm{~L} / \mathrm{min}$ and size of the particles obtained spray, ranged from 0.5 to $6.0 \mathrm{Nm}$. The flow of dispersed liquid was $0,2 \mathrm{ml} /$ min. A typical dosage of a benzodiazepine aerosol is either administered as a single inhalation or as a series of inhalations taken within 5 minutes or less (dosage equals sum of inhaled amounts). After the inhalation, parameters of lung function were measured again. Then, we repeated methacholine inhalation in increased doses, in the same manner as on the previous day.

Statistical analysis of the results included the calculation of the mean value $(\mathrm{X})$, standard deviation (SD) and standard error (SE) for all measured lung function parameters. To determine statistical significance, data were tested by t-test, a threshold value included changes in the level of statistical significance of $\mathrm{p}<0.05$.

\section{Results}

The population examined consisted of 12 patients with well controlled asthma in which we examined the response of the airways to increasing doses of methacholine with inhalative application of diazepam. The anthropometric data and lung function parameters are given in Table 1 and 2. Seven patients were women and five men. Their age ranged from 32 to 59 years. Only patients which $\mathrm{FEV}_{1}$ declined in more then $20 \%$ after inhalation of one of the doses of methacholine were analyzed. After application of methacholine dose of $0.6 \mathrm{mg} /$ $\mathrm{mL}$, six (50\%) subjects responded with an increase of resistance of more than $20 \%$,after application of methacholine dose of 0.2 and $6.0 \mathrm{mg} / \mathrm{ml}$, four patients had the same response, and two patients (16.6\%) had significant bronchoconstriction to methacholine dose of $2.0 \mathrm{mg} / \mathrm{mL}$.

The characteristic response to increasing doses 
Table 1. Anthropometric measures of patients treated with methacholine and benzodiazepines

\begin{tabular}{|lll|}
\hline Anthropometric measures & $\mathbf{X} \pm$ SD & (SE) \\
\hline Age (years) & $48.5 \pm 10.9$ & $(3.1)$ \\
\hline Body height $(\mathrm{cm})$ & $164.2 \pm 8.5$ & $(2.4)$ \\
\hline Body weight $(\mathrm{kg})$ & $73.7 \pm 12.6$ & $(3.6)$ \\
\hline Broca index $(\%)$ & $115.5 \pm 21.3$ & $(6.1)$ \\
\hline Number of respondents & 12 & \\
\hline
\end{tabular}

Table 2. Mean values of lung function of asthmatic patients who are treated by methacholine and benzodiazepine

\begin{tabular}{|c|c|c|}
\hline $\begin{array}{l}\text { Parameters of lung } \\
\text { function }\end{array}$ & $X \pm S D$ & (SE) \\
\hline VC (\%) & $92.9 \pm 16.0$ & $(4.6)$ \\
\hline $\mathrm{FEV}_{1}(\%)$ & $83.3 \pm 31.4$ & $(9.0)$ \\
\hline $100 \times \mathrm{FEV}_{1} / \mathrm{NC}(\%)$ & $68.0 \pm 23.2$ & $(6.7)$ \\
\hline Rt & $0.1 \pm 0.06$ & $(0.02)$ \\
\hline ITGV (L) & $1.74 \pm 0.6$ & $(0.2)$ \\
\hline Srt (kPa $\cdot \mathrm{s})$ & $0.3 \pm 0.16$ & $(0.04)$ \\
\hline $\mathrm{PaO}_{2}(\mathrm{mmHg})$ & $75.3 \pm 5.9$ & $(1.7)$ \\
\hline $\mathrm{PaCO}_{2}(\mathrm{mmHg})$ & $35.4 \pm 10.3$ & $(2.9)$ \\
\hline $\mathrm{pH}$ & $7.4 \pm 0.02$ & $(0.006)$ \\
\hline Number of respondents & 12 & \\
\hline
\end{tabular}

of inhaled methacholine is shown in Figures 1 and 2. Figure 1 shows the effect of methacholine on the value of $\mathrm{VC}$ of patients with asthma, before and after inhalation of diazepam. On the first day of testing, giving methacholine provoked the dose-dependent response and reduction of VC. After inhalation of $6 \mathrm{mg} / \mathrm{ml}$ of methacholine, the values od VC significantly fell from $4.2 \mathrm{~L}$ to $2.7 \mathrm{~L}$. Even 30 minutes after the provocation, $\mathrm{VC}$ values did not return to normal. However, in panel A it is shown that on the second day of testing, prior to the administration of diazepam, VC was 3.74 $\mathrm{L}$ in the same patient. After administration of the diazepam and methacholine (dose of $6 \mathrm{mg} / \mathrm{ml}$ ), change in values of VC were significantly higher, $3.98 \mathrm{~L}$, which means that VC increased and not decreased as compared to the initial value. VC was not significantly changed even after 30 minutes of testing (3.72 L) (Figure 1).

Figure 2 shows the effect of methacholine on the value of $\mathrm{FEV}_{1}$ in patients with asthma, before and after inhalation of diazepam. In the first day of testing, methacholine inhalation $(6 \mathrm{mg} / \mathrm{mL})$ led to a significant drop in the value of $\mathrm{FEV}_{1}$ from $2.98 \mathrm{~L}$ to $1.69 \mathrm{~L}$. On the second day of study, in the same patients, pretreatment with diazepam reduced the changes of $\mathrm{FEV}_{1}$, so that upon inhalation of methacoline the values of $\mathrm{FEV}_{1}$ droped from 2.48 $\mathrm{L}$ to $2.21 \mathrm{~L}$.

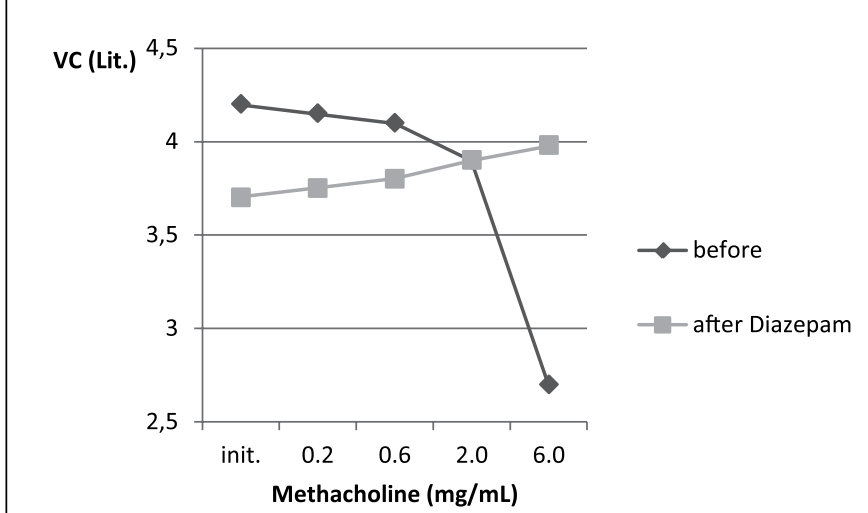

Panel A

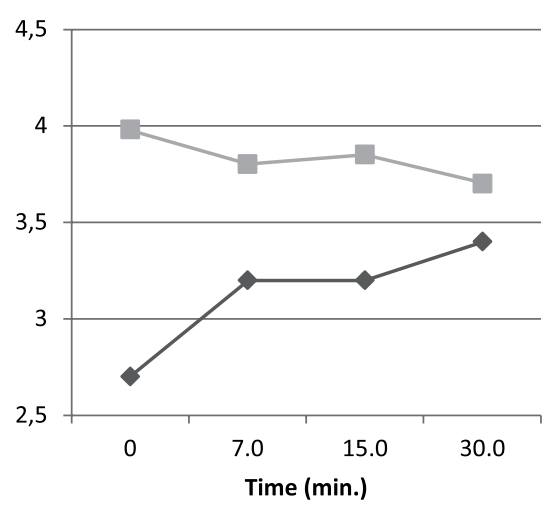

Panel B

Figure 1. Effect of methacholine on the value of vital capacity (VC) in patients with asthma before and after inhalation of diazepam. Panel A: On the first day of study, methacholine given by inhalation caused dose-dependent response, and reduction of VC. On the second day test, previously given diazepam significantly decreased the change of VC. Panel B: shows motion of the value in VC, and response on methacholine in relation to time (30 minutes), before $(2.7 \mathrm{~L})$ and after $(2.21 \mathrm{~L})$ inhalation of diazepam. 


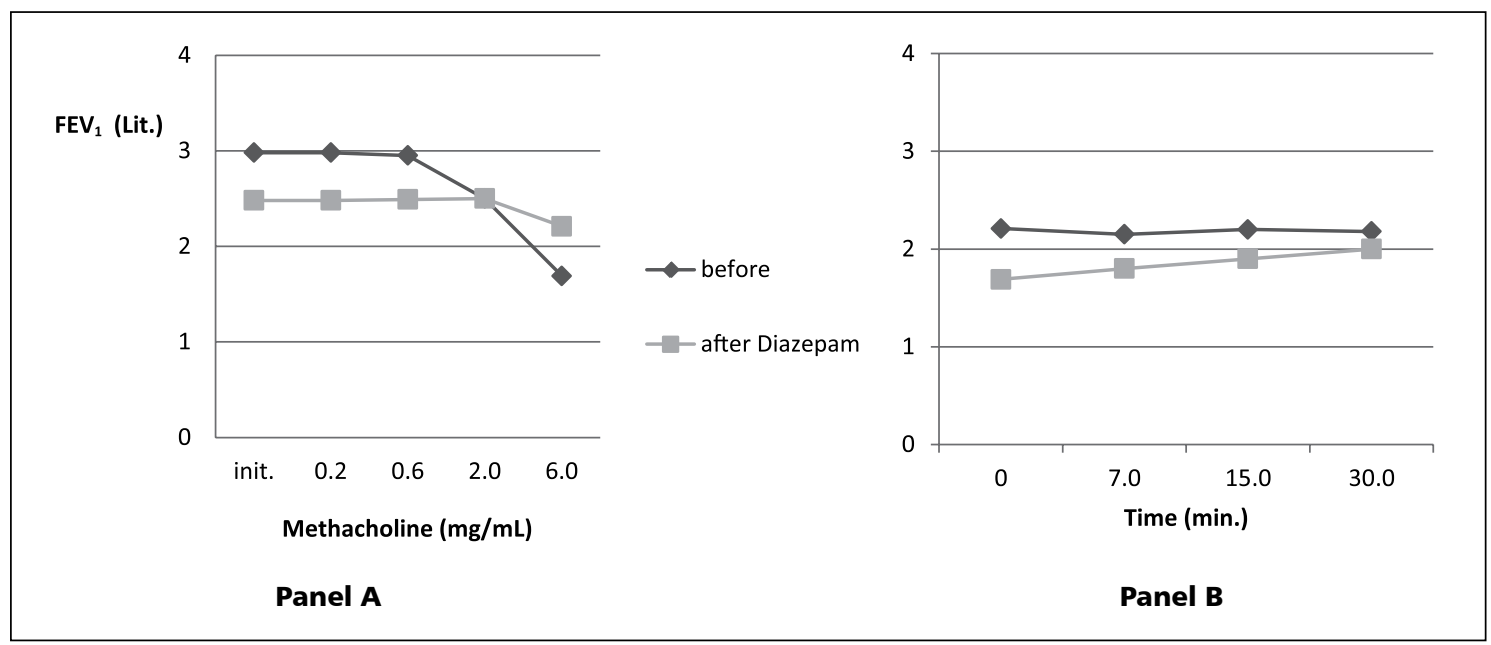

Figure 2. The effect of methacholine on values of forced expiratory volume in first second $\left(\mathrm{FEV}_{1}\right)$ of patients with asthma, before and after inhalation of diazepam. Panel A: The first day of testing, inhalation of methacholine caused a dose dependent response and the reduction of $\mathrm{FEV}_{1}$. On the second day of study, previously given diazepam lowered the changes of FEV ${ }_{1}$ curve. Panel B: Shows movement of $\mathrm{FEV}_{1}$ and response to methacholine in relation to time (30 minutes), prior to (1.69 L) and $\operatorname{after}(2.21 \mathrm{~L})$ inhalation of benzodiazepines.

Figure 3 and 4 present summarized data of the relationship between $\mathrm{VC}$ and FEV, where patients were treated only with methacholine and methacholine with previous administration of diazepam. VC is given as a function of changes in the static parameters of lung function, $\mathrm{FEV}_{1}$ indicates a change of the dynamic parameters of lung function .

Figure 3 shows the effect of diazepam on changes of VC caused by inhalation of metha- choline in patients with asthma. On the first day of study, administering methacholine reduced VC of patients (from 3.8 L to $3.1 \mathrm{~L})(\mathrm{p}<0.05$, $\mathrm{n}=12$ ). On the second day of testing, changes in VC after inhalation of methacholine were not significant if diazepam had been previously inhaled in a concentration of $1.7 \cdot 10-2 \mathrm{M}$, for a period of 5 minutes $(p>0.5)$. Values are given as mean values of $\mathrm{X} \pm \mathrm{SE}$.

The graph 4 shows the cumulative change in

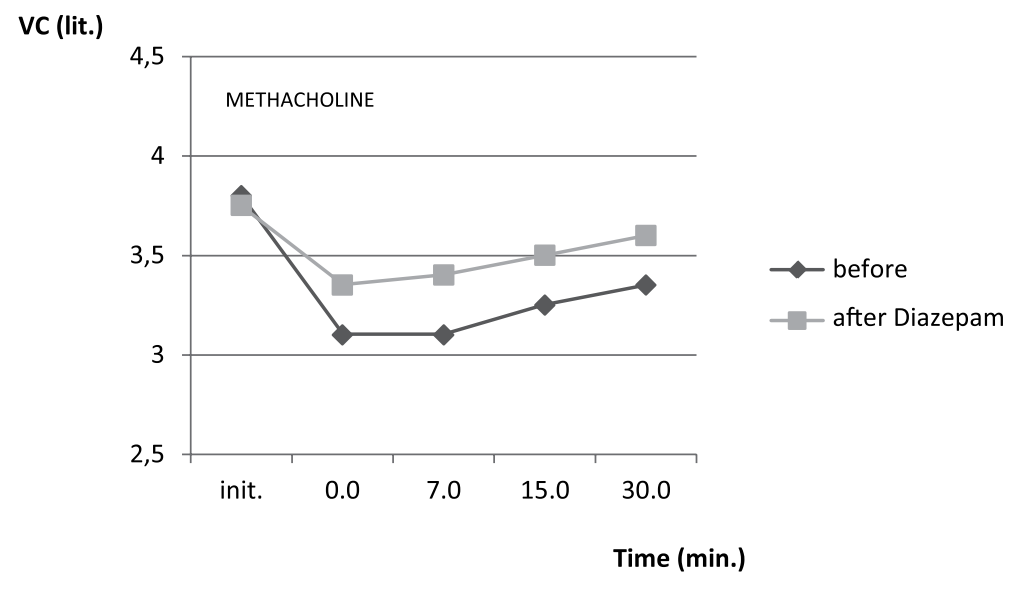

Figure 3. The effect of benzodiazepines on the changes of VC induced by methacholine in patients with asthma. On the first day of study, methacholine given by inhalation resulted in the decrease in VC of tested patients. In the second day of testing, a changes in VC after inhaled methacholine were not significant, if previously benzodiazepines (diazepam) were inhaled. Values are given as mean values of $\mathrm{X} \pm \mathrm{SE}$. 


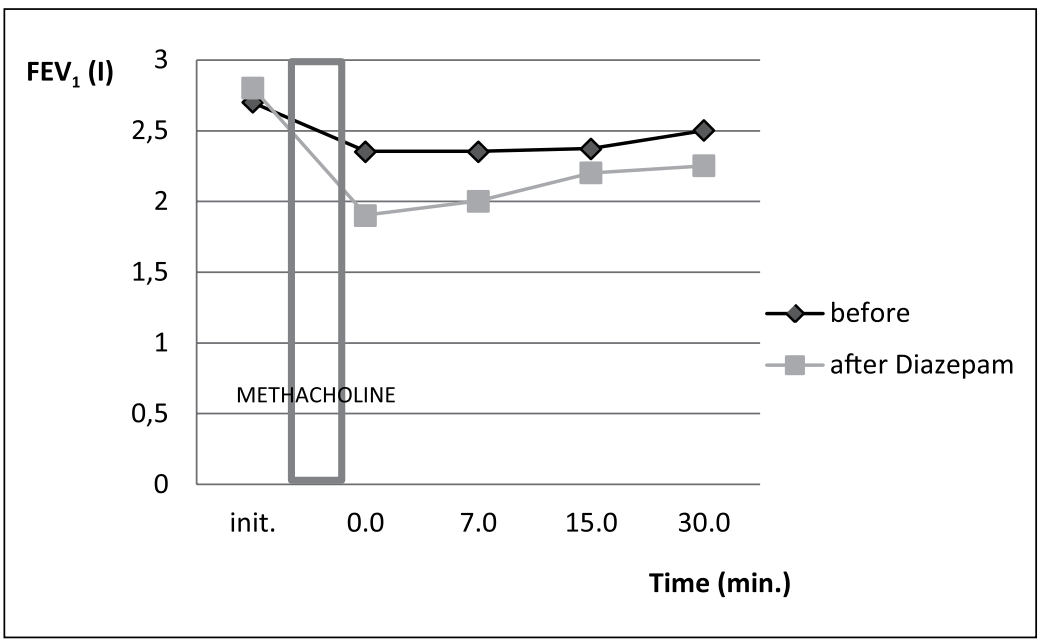

Figure 4. The effect of benzodiazepines on the change in $\mathrm{FEV}_{1}$, caused by methacholine in patients with asthma. Given methacholine resulted in the decrease of $\mathrm{FEV}_{1}(\mathrm{p}$ $<0.05, \mathrm{n}=12)$. On the second day of study, the changes in $\mathrm{FEV}_{1}$ after inhalation of methacholine were not significant, if benzodiazepines were previously inhaled in 5 minutes. ( $p$ $>0.5)$. Values are given as mean values of $X \pm S E$.
$\mathrm{FEV}_{1}$ data, wherein the patients were only treated with methacholine and methacholine with previous administration of diazepam, $\mathrm{FEV}_{1}$ was given as a function of changes in the dynamic parameter of lung function. In Figure 4 a significant decline in $\mathrm{FEV}_{1}$ is noticeable after the administration of methacholine from $2.8 \mathrm{~L}$ to $1.9 \mathrm{~L}$ ( $\mathrm{p}<0.005)$. In this case, also, the $\mathrm{FEV}_{1}$ curve was normalized even after $30 \mathrm{~min}(2.2 \mathrm{~L})$. The previous administration of diazepam showed no significant changes at $\mathrm{FEV}_{1}$ curve to the provocation, which means that diazepam diminished the effects of methacholine.

\section{Discussion and Conclusions}

The smooth muscle of the airways from the trachea down to the alveolar ducts is under the control of efferent fibers of the autonomic nervous system. Different typical transmitters and peptides participate in regulation of contractility of airway smooth muscle (opioid, GABA, serotonin, tachykinin and glutamat). Airway preganglionic nerve activity is regulated by subsets of pulmonary and extrapulmonary afferent nerve fibers, which continuously provide polysynaptic input to brain stem preganglionic nuclei ${ }^{22-24}$.

On the basis of our present knowledge, clinical tests and experimental studies, the hypothesis that increased cholinergic activity leads to bronchoconstriction and that it may be blocked or reduced by administering inhaled diazepam, is confirmed.
Airway effector cells (bronchial and vascularsmooth muscle and glands) are densely, albeit differentially,innervated by fibers derived from both the parasympathetic and sympathetic nervous system which regulate airway smooth-muscle tone, glandular secretion and blood-vessel diameter. Autonomic innervation of the airways is derived primarily from the parasympathetic nervous system ${ }^{1,3,24}$.

Benzodiazepines are drugs that have direct and indirect bronchodilatory effect on the smooth muscle of the airways, directly by inhibiting a voltage-dependent $\mathrm{Ca}^{2}+$ channels, and indirectly by increasing neurotransmision role of GABA at postsynaptic receptors, resulting in an increase in the number of open channels for chloride ${ }^{10-12}$. Benzodiazepine receptor agonists increase the affinity of GABA to its receptor. The bronchodilatory effect of diazepam indicates its potential application in the treatment of acute exacerbation of asthma ${ }^{25-27}$.

It is known that GABA-B-specific agonists decrease airway responsiveness to various bronchoconstricting agents by modulating presynaptic acetylcholine release from parasympathetic nerves. On the other hand, a GABA-B receptor agonist, baclofen, can worsen airway responses following the administration of methacholine to asthmatic patients. This paradoxical enhancement by baclofen of airway responsiveness led us to hypothesize that there may be postganglionic (i.e., smooth muscle) GABA-B functional receptors that couple 
to the Gi protein, known to impair relaxation of airway smooth muscle ${ }^{28-31}$. Many laboratory examinations proved that except diazepam, many other derivates of GABA for example baclofen effects on spinal respiratory neurons depending on doses. Low doses of baclofen from $(0,5-2 \mathrm{mg} / \mathrm{kg})$ increases frequency action potentials on phrenic and intercostal neurons. Middle dose of 2-4 mg/ $\mathrm{kg}$ increases the lasting of inspiration. Higher dose $4-10 \mathrm{mg} / \mathrm{kg}$ paralyses the inspiration. The common things about these two medicines are that their effect on central neurons is dose dependent and muscle relaxant $\mathrm{t}^{30-32}$.

From previous experience, it can be concluded that increased parasympathetic innervation, which leads to constriction of bronchi, becomes blocked or reduced by giving GABA or medicines that are GABA's derivates. GABA has relaxing effect by inhibiting muscle conduction, by decreasing resistance in airway breathing channels and by decreasing contractility of trachea muscle. The same effect produce benzodiazepines by increasing GABA secretion indirectly ${ }^{13,23-25}$. Our research shows that benzodiazepines have bronchodilatory effect on the smooth muscle of the airways.

Methacholine is a synthetic choline ester that mimics the effects of parasympathetic innervation of the musculature of the respiratory tract, thus causing constriction of the bronchi. For this reason, methacholine may be used as a pharmaceutical in broncho provocation tests for the detection of bronchial reactivity ${ }^{3,10,15}$ and also for this reason we used it in this clinical trial, as a drug that provokes bronchoconstriction.

Based on this research results in patients with asthma, we conclud that the bronchoconstrictor effects of methacholine in patients with asthma is significantly reduced if the patient has previously inhaled diazepam.

\section{References}

1. Kaicker J, Dang W, D’Urzo A. The challenge of objective confirmation of asthma diagnosis in primary care. NPJ Prim Care Respir Med 2014; 24: 14032.

2. Dekkers BG, Maarsingh H, Meurs H, Gosens R. Airway structural components drive airway smooth muscle remodeling in asthma. Proc Am Thorac Soc 2009; 6 (8): 683-92.

3. An SS, Bai TR, Bates JH, Black JL, Brown RH. Airway smooth muscle dynamics: a common pathway of airway obstruction in asthma. Eur Respir J 2007; 29 (5): 83460.

4. Haxhiu MA, Erokwu B, Bhardwaj V, Dreshaj IA. The role of the medullary raphe nuclei in regulation of cholinergic outflow to the airways. J Auton Nerv Syst 1998; 69 (1): 64-71.

5. Chapman RW, Danko G, Rizzo C, Egan RW, Mauser PJ, Kreutner W. Prejunctional GABA-B inhibition of cholinergic, neurally-mediated airway contractions in guinea-pigs. Pulm Pharmacol 1991; 4 (4): 218-24.

6. Bolser DC, DeGennaro FC, O'Reilly S. Peripheral and central sites of action of GABA-B agonists to inhibit the cough reflex in the cat and guinea pig. Br J Pharmacol 1994; 113 (4): 1344-8.

7. Chapman RW, Hey JA, Rizzo CA, Bolser DC. GABA-B receptors in the lung. Trends Pharmacol Sci 1993; 14 (1): 26-9.

8. Moore CT, Wilson CG, Mayer CA, Acquah SS, Massari VJ, Haxhiu MA. GABAergic inhibitory microcircuit controlling cholinergic outflow to the airways. J Appl Physiol 2004; 96 (1): 260-70.

9. Advenier C, Devillier P, Blanc M, Gnassounou JP. Peripheral type benzodiazepine receptors and response to adenosine on the guinea-pig isolated trachea. Pulm Pharmacol 1990; 3 (3): 137-44.

10. Galleguillos T, Risco L, Garay JL, González M, Vogel M. Benzodiazepine use in primary care patients. Rev Med Chile 2003; 131 (5): 535-40.

11. Candenas ML, Devillier P, Naline E, Advenier C. Influence of diazepam, alpidem, zolpidem and zopiclone, on the response to adenosine of the guinea pig isolated trachea.Fundam Clin Pharmacol 1991; 5 (1): 1-10.

12. Vinkers CH, Tijdink JK, Luykx JJ, Vis R. Choosing the correct benzodiazepine: mechanism of action and pharmacokinetics. Ned Tijdschr Geneeskd 2012; 155 (35): A4900.

13. Formiga F, Duaso E, Ruiz D, San José A, Urrutia A, López-Soto A. Use of benzodiazepines according to the admission diagnosis. Med Clin (Barc) 2012; 139 (12): 531-4.

14. Matera MG, D’Agostino B, Costantino M, Mangrella M, Calderaro V, Rossi F. K+ channels and guinea-pig trachea: a possible functional modulation by GABA-B receptors. Pulm Pharmacol 1994; 7 (4): 259-63.

15. Kim MH, Song WJ, Kim TW, Jin HJ, Sin YS, Ye YM, et al. Diagnostic properties of the methacholine and mannitol bronchial challenge tests: a comparison study. Respirology 2014; 19 (6): 852-6.

16. Singh D, Corradi M, Bindi E, Baronio R, Petruzzelli S, Paggiaro P. Relief of methacholine-induced bronchos- 
pasm with extrafine beclomethasone dipropionate/ formoterol in comparison with salbutamol in asthma. Pulm Pharmacol Ther 2012; 25 (5): 392-8.

17. Tie ST, Wong JL, Beniyamin A, Ho A, Kannan SK, Jamalul Azizi AR. Methacholine challenge test as an adjunctive investigative tool in patients with asthma-like symptoms: the Sabah experience. Med J Malaysia 2012; 67 (2): 204-6.

18. Dubois AB, Botelho SY, Bedell GN, Marshall R, Comroe $\mathrm{JH}$. A rapid plethysmographic method for measuring thoracic gas volume. J Clin Invest 1956; 35: 322-6.

19. Burrows B, Sears MR, Flannery EM, Heribson GP, Holdaway MD. Relationships of bronchial responsiveness assessed by methacholine to serum IgE, lung function, symptoms, and diagnoses in 11-year ol New Zeland children. J Allergy Clin Immunol 1992; 90: 376-85.

20. Miric M. Neuromodulatory role of GABA and benzodiazepine system in regulation of airways [dissertation]. Pristina: University of Pristina; 1994.

21. Eiser NM, Kerrebijn PH, Quanjer PH. SEPCR Working group "Bronchial hyperreactivity". Guidelines for standardization of bronchial challenges with (nonspecific) bronchoconstricting agents. J Asthma 2009; 22 (6): 303-29.

22. Ezure K, Tanaka I. Lung inflation inhibits rapidly adapting receptor relay neurons in the rat. Neuroreport 2000; 11 (8): 1709-12.

23. Tamaoki J, Graf PD, Nadel JA. Effect of gamma-aminobutyric acid on neurally mediated contraction of guinea pig trachealis smooth muscle. J Pharmacol Exp Ther 1987; 243 (1): 86-90.
24. Osawa Y, Xu D, Sternberg D, Sonett JR. Functional expression of the GABA-B receptor in human airway smooth muscle. Am J Physiol Lung Cell Mol Physiol 2006; 291 (5): L923-31.

25. Koga Y, Sato S, Sodeyama N. Comparison of the relaxant effects of diazepam, flunitrazepam and midazolam on airway smooth muscle. Br J Anaesth 1992; 69 (1): 65-9.

26. Haxhiu MA, van Lunteren E, Cherniack NS, Deal EC. Benzodiazepines acting on ventral surface of medulla cause airway dilation. Am J Physiol 1989; 257 (4 pt 2): R810-5.

27. Mellegers MA, Furlan AD, Mailis A. Gabapentin for neuropathic pain: systematic review of controlled and uncontrolled literature. Clin J Pain 2001; 17 (4): 284-95.

28. Raeburn D, Miller LG, Summer WR. Peripheral type benzodiazepine receptor and airway smooth muscle relaxation. J Pharmacol Exp Ther1988; 245 (2): 557-62.

29. Dicpinigaitis PV, Spungen AM, Bauman WA, Absgarten A, Almenoff PL. Inhibition of bronchial hyperresponsiveness by the GABA-agonist baclofen. Chest 1994; 106 (3): 758-61.

30. Dicpinigaitis PV. Effect of the GABA-agonist baclofen on bronchial responsiveness in asthmatics. Pulm Pharmacol Ther 1999; 12 (4): 257-60.

31. Seifert E, Trippenbach T. Baclofen attenuates cardiorespiratory effects of vagal C fiber stimulation in rats. Can J Physiol Pharmacol 1995; 73 (10): 1485-94.

32. Field JJ, Stocks J, Kirkham FJ, Rosen CL, Dietzen DJ, Semon T, et al. Airway hyper responsiveness in children with sickle cell anemia. Chest 2011; 139 (3): 563-8. 